This document is the accepted manuscript version of the following article: Meyer, Q., Ashton, S., Jervis, R., Finegan, D. P., Boillat, P., Cochet, M., ... Brett, D. J. L. (2015). The hydro-electro-thermal performance of air-cooled, open-cathode polymer electrolyte fuel cells: combined localised current density, temperature and water mapping. Electrochimica Acta, 180, 307-315. https://doi.org/10.1016/j.electacta.2015.08.106

This manuscript version is made available under the CC-BY-NC-ND 4.0 1icense http: //creativecommons .org/1icenses/by-nc-nd/4.0/

\title{
The Hydro-electro-thermal Performance of Air-cooled, Open-cathode Polymer \\ Electrolyte Fuel Cells: Combined Localised Current Density, Temperature and Water Mapping
}

\author{
Quentin Meyer ${ }^{1}$, Sean Ashton ${ }^{2}$, Rhodri Jervis ${ }^{1}$, Donal P. Finegan ${ }^{1}$, Pierre Boillat ${ }^{3,4}$, \\ Magali Cochet ${ }^{3}$, Oliver Curnick², Tobias Reisch², Paul Adcock ${ }^{2}$, Paul R. Shearing ${ }^{*}, 5$, \\ Dan J. L. Brett ${ }^{*}$
}

${ }^{1}$ Electrochemical Innovation Lab, Department of Chemical Engineering, UCL, London, WC1E 7JE, United Kingdom.

${ }^{2}$ Intelligent Energy, Charnwood Building Holywell Park, Ashby Road, Loughborough Leicestershire, LE11 3GB, United Kingdom.

${ }^{3}$ Electrochemistry Laboratory (LEC), Paul Scherrer Institute (PSI), 5232 Villigen, Switzerland.

${ }^{4}$ Neutron Imaging and Activation Group (NIAG), Paul Scherrer Institute (PSI), 5232 Villigen, Switzerland.

${ }^{5}$ UCL/Zeiss Centre for Correlative X-ray Microscopy, UCL, London, WC1E 7JE, United Kingdom

* Author to whom correspondence should be addressed

Tel.: +44(0)2076793310

Web: www.ucl.ac.uk/electrochemical-innovation-lab

Email: d.brett@ucl.ac.uk; p.shearing@ucl.ac.uk 


\section{Abstract}

In situ diagnostic techniques provide a means of understanding the internal workings of fuel cells so that improved designs and operating regimes can be identified. Here, a novel metrology approach is reported that combines current and temperature mapping with water visualisation using neutron radiography.

The approach enables a hydro-electro-thermal performance map to be generated that is applied to an air-cooled, open-cathode polymer electrolyte fuel cell. This type of fuel cell exhibits a particularly interesting coupled relationship between water, current and heat, as the air supply has the due role of cooling the stack as well as providing the cathode reactant feed via a single source. It is found that water predominantly accumulates under the cooling channels (thickness of 70-100 $\mu \mathrm{m}$ under the cooling channels and $5-25 \mu \mathrm{m}$ in the active channels at $0.5 \mathrm{~A} \mathrm{~cm}^{-2}$ ), in a similar fashion to the lands in a closed-cathode design, but contrary to passive opencathode systems. The relationship between current, temperature and water accumulation is complex and highly dependent on location within the cell. However, there is a general trend that higher currents and cooling limitations, especially above $0.7 \mathrm{~A} \mathrm{~cm}^{-2}$ and below $3.9 \times 10^{-3} \mathrm{~m}^{3} \mathrm{~s}^{-1}$, leads to temperatures above $60{ }^{\circ} \mathrm{C}$, which dehydrate the membrane (water thickness of 10-25 um) and the cell operates below $0.5 \mathrm{~V}$.

\section{Keywords}

Air-cooled open-cathode polymer electrolyte fuel cell; water mapping; neutron imaging; temperature mapping; current mapping. 


\section{Introduction}

Polymer electrolyte fuel cells (PEFC) fuelled with hydrogen are among the most promising energy conversion technologies for a broad range of applications, including portable, stationary and automotive power delivery. A range of diagnosis techniques have been developed to understand and improve the heat and water management in these devices with a view to improving performance, extending durability and informing advanced design.

\subsection{Current and temperature mapping in fuel cells}

Current mapping studies have proven to be insightful and revealed large current density gradients attributed to factors such as: uneven fuel consumptions [1-4], operating conditions [5-7], stoichiometric ratios [8-11], the reactant flow orientation $[3,7]$, and water management issues [12].

Temperature distribution has also been extensively studied, identifying areas of higher electrochemical activity, hot-spot formation and fuel depletion. Thermocouples can provide a crude measure of temperature inside fuel cells [13-16] but cannot provide high spatial resolution. Moreover, thermocouples need to be inserted inside the fuel cell, which often requires design modifications. In contrast, infrared thermal imaging can provide very high spatial and temperature resolution [17-22], yet typically requires use of modified fuel cells with an infrared transparent window, or is otherwise confined to open-cathode fuel cells [23-25] or the outer surface of a cell or stack $[26,27]$. 
Combined temperature and current mapping studies offer an extra dimension of information and allow the impact of each parameter on the other to be assessed $[15,26,19,27]$; however, the other important component in this equation, water, needs to be considered in unison to see the whole picture.

\subsection{Liquid water mapping in fuel cells}

Effective water management is of paramount importance for fuel cell operation (dehydration / flooding can lead to performance decay and stack failure). Water generation and removal, and transport processes in the gas diffusion layer, membrane and flow-field have been extensively modelled [30-36]. However, the reliability of these models depends on the level of validation, which requires appropriate experimental inputs. Therefore, a number of experimental methods have been investigated, in order to evaluate, quantify, measure and / or visualise the water dynamics and distribution under different modes of operation. Such techniques should ideally satisfy three requirements as defined by Stumper et al. [37]: (i) in situ applicability, (ii) minimal invasiveness and (iii) ability to provide information on the distribution of liquid water over the active area.

High frequency impedance enables the ohmic resistance of a fuel cell to be measured, which can be used to monitor changes in the membrane conductivity, and therefore hydration content $[1,7,16,29,38-44]$. Localised electrochemical impedance spectroscopy (EIS) has been achieved as well, and provides more insight on the hydration / dehydration processes distributed across electrodes [1,5,29,45].

To investigate water content, it is possible to weigh the fuel cell before and after operation [46], or to visualise liquid water via optical imaging open channels $[24,47]$. These methods are attractive because of their simplicity, but the most powerful method for water visualisation, (satisfying all three criteria from Stumper et al. [37]) is 
neutron imaging. This technique is based on attenuation of a neutron by hydrogencontaining compounds such as water, and transparency to neutrons of most fuel cell construction materials (aluminium, stainless steel). Neutron imaging can identify water in the in-plane orientation (with the membrane place parallel to the beam) and through-plane orientation (with the membrane plane perpendicular to the beam), enabling in the first case to differentiate the water content from the cathode and the anode [48-50] and in the second case the effect of different designs, components, and operating conditions [45,51-65]. Neutron imaging has been combined with other modelling and experimental techniques, such as current mapping [66], CFD models validation [32,51,65], optical imaging [47], neutron scattering [61] and localised EIS [45].

\subsection{Air-cooled, Open-Cathode Fuel Cells}

Unlike conventional closed-cathode fuel cells, self-breathing fuel cells offer the advantages of simpler design and integration into systems, using diffusion from the atmosphere without compressors. Passive air-breathing systems are typically limited to a maximum current density of $\sim 0.6 \mathrm{~A} \mathrm{~cm}^{-2}$ [67-71] due to heat and water management issues, since water cannot be removed from the membrane, except through evaporation [69,72]. In the so-called 'air-cooled, open-cathode' configuration, air is forced through the cathode channels using fans, which improves performance and enables higher current densities to be attained [73-77]. In aircooled, open-cathode systems the temperature depends on the voltage and current density $[46,67]$, air cooling flow rate $[73,76]$, and heat transfer characteristics of the stack. Temperature monitoring is therefore crucial to ensure effective and durable operation. In practice, this is normally performed using a single-point thermocouple inserted in the centre of the cell $[16,26,75]$, or for development work using multiple micro thermocouple measurements at various locations in the fuel cell $[13,78,79]$. 
Here, we present the results obtained by applying a novel metrology approach to an air-cooled, open-cathode two-cell stack, operated without external humidification: the technique combines water visualisation using neutron imaging, with current and temperature mapping using a printed circuit board (PCB) sensor plate [80]. The effect and relationship between the key hydro-electro-thermal properties allows important new insight into this type of fuel cell to be achieved.

\section{Experimental}

Fuel cell testing - A 2-cell (60 $\mathrm{cm}^{2}$ active area) air-cooled / air-breathing fuel cell stack was used for testing (Intelligent Energy Ltd., UK). The membrane electrode assembly was composed of commercially available gas diffusion layers (GDLs) and commercially available membranes with Pt loading of 0.1 and $0.4 \mathrm{mg} \mathrm{cm}^{-2}$ on the anode and cathode, respectively.

The test station [26] supplied dry hydrogen at ambient temperature (with a purity of $99.995 \%)$ to the anodes and air was forced through the stack by a single fan (SanAce 36, Sanyo Denki) to the open-cathode channels (Figure 1). The exhaust hydrogen flow rate in through-flow mode was measured using a thermal mass flow meter (MassVIEW, Bronkhorst) to be 4.7 SLPM, which ensures a stoichiometric ratio of 2 at $1 \mathrm{~A} \mathrm{~cm}^{-2}$. The fans, which provide cooling and air supply to the cathode, were controlled by a programmable power supply (3649A Agilent). The current drawn from the PEFC was controlled using an electronic load (PLZ664WA, Kikusui) in galvanostatic mode. An in-house computer controlled system controls the air, hydrogen, cooling and electrical valves (LabVIEW, National Instruments) as well as recording and presenting data using a data acquisition card (USB 6363, National Instruments). Ambient temperature, pressure (absolute) and relative humidity $(\mathrm{RH})$ were measured at $25{ }^{\circ} \mathrm{C} \pm 0.2{ }^{\circ} \mathrm{C}, 0.97 \pm 0.02$ bar and $40 \% \mathrm{RH}$ respectively, during 
all tests. The operation of this fuel cell in terms of cathode design, cooling and active channels and materials $[26,27]$, temperature uncertainty [27] and water management in dead-ended anode mode [26], has been described in previous reports. In this work the anode and cathode are operated in through-flow mode.

\section{Current and temperature mapping}

Current and temperature mapping were performed using a 16-segment printed circuit board sensor plate ( $\mathrm{S}_{++}$Simulation Services, Germany). Each segment covers an area of $3.75 \mathrm{~cm}^{2}$. The temperature is measured using copper 'meanders' with a $2 \mathrm{~mA}$ current applied, as the resistance of copper is very sensitive to temperature changes; the local current at each contact was measured using shunt resistors made of a special alloy insensitive to temperature changes. Further details on the approach can be found in previously published work.[80]

\section{Neutron imaging facility}

Neutron radiography was performed at the neutron imaging facility NEUTRA of the SINQ spallation source (Paul Scherrer Institute, Switzerland) [81]. Thermal neutrons provided by the source are extracted from a moderator tank in the thermal energy range of $1 \times 10^{-3}$ to $10 \mathrm{eV}$ with a Maxwellian spectrum energy of $25 \times 10^{-3} \mathrm{eV}$. The third position was used on the beamline since it offers a beam diameter of $40 \mathrm{~cm}$ [81], and a maximal detector field of view of $36 \times 38 \mathrm{~cm}$, hence suitable for larger scale samples. In order to image the water distribution over the entire surface of the electrodes area, the cell faced the neutron beam in through-plane orientation (Figure 1 a-b). The detector consists of a neutron-sensitive LiF/ZnS scintillator and a chargecoupled CCD device (Ikon-L, Andor) camera housed in a light-tight box (Figure $1 \mathrm{a}$ ). The neutron beam is converted into a photonic field by the scintillator, whereby the intensity of evoked light is proportional to the intensity of the incoming neutron beam [56]. 
Measurements were performed with an exposure time of $10 \mathrm{~s}$ (time during which the camera opens a built-in shutter and integrates the light), and a sampling time of 2-3 s per image (time during which the image is processed), for sufficient resolution and noise reduction. This exposure time is well within the range typically used for neutron imaging on PEFCs (typically between 1 and 25 s [45,51-59,82]). Since the current study investigates steady-state operation, the $12 \mathrm{~s}$ temporal resolution is sufficient. The intensity images are generated in FITS format, and are processed using PSI inhouse software written in the IDL language.

\section{Quantification of the water thickness from neutron images}

All the materials of the cell contribute to the attenuation of the transmitted neutron beam, following the Beer-Lambert law (Equation 1).

$I / I_{0}=\exp \left(-\mu_{\text {water }} t_{\text {water }}\right)$

With I the intensity of the beam in operation, $I_{0}$ the intensity of the beam for the dry cell (without water), $\mu_{\text {water }}$ the attenuation coefficient of water, $t_{\text {water }}$ the thickness of water. $I$ and $I_{o}$ are determined after all necessary corrections (filtering, subtraction of background components, alignment of "working" and reference images) [83].

The water thickness is then extracted by taking the logarithm, divided by the attenuation coefficient $\mu_{\text {water }}$.

$t_{\text {water }}=-\frac{\ln \left(I / I_{o}\right)}{\mu_{\text {water }}}$

In our case, $\mu_{\text {water }}$, the attenuation coefficient of neutrons in liquid water, was measured in the NEUTRA beamline for the given setup at $3.5 \mathrm{~cm}^{-1}$ [84]. In the 
following sections, the water content will be expressed as the effective water thickness $t_{\text {water }}$ in $\mu \mathrm{m}$.

\section{Results}

\subsection{Sensor plate neutron transparency}

The sensor plate was imaged at the Paul Scherrer Institute prior to its insertion in the stack and was found to be $80 \%$ transparent, which is suitable for imaging. Therefore, the combined neutron imaging and current and temperature mapping is possible with this choice of hardware. The sensor plate is inserted between the first and the second cell (Figure 2c), to measure the average current and temperature distribution of both cells.

\subsection{Neutron imaging for water visualisation}

Although high frequency EIS provides a useful indication of the membrane conductivity, it is limited in spatial resolution to the size of the localised current collector. In EIS, it is common to assume that changes in the purely Ohmic resistance are due to the electrolyte membrane (and its water content); however, other factors such as changes in contact resistance associated with membrane swelling can complicate interpretation of this electrical measurement. Neutron imaging allows a high resolution map of the water distribution to be generated that can unequivocally discern between the water in the channel and under the land positions. It is the combination of these techniques, with knowledge of the local temperature, that makes this correlative approach particularly powerful. 
The stack technology investigated uses an electrically insulating layer between the endplates and the current collector / bipolar plates. This is relatively opaque to neutrons; therefore, a modification was made to the insulating layer so as to retain functionality but allow substantial open areas so that water imaging could take place. This resulted in the opaque pattern shown in Figure $2(a-b)$. Since the cell is operated using dry gases, at open circuit potential, it does not have any water (Figure 2a).

Throughout this study, a two cell stack is imaged, for enhancement of water detection and behaviour closer to stack operation (Figure $2 \mathrm{c}$ ). A water 'thickness' of $75 \mu \mathrm{m}$ per cell is within the range of water contents previously reported for single cells $(30-2000 \mu \mathrm{m}) \quad[47,54,55,85,86]$.

Under practical operation of this commercial stack technology, a single thermocouple is inserted into the central cooling channel for monitoring and control purposes. Therefore, when considering overall performance compared to cell temperature and average current density, the water content of the central cooling channel (Figure 2 b) is used.

A special variation in water thickness is consistently observed, as seen by the repeating sequence of blue and yellow regions in Figure $2 \mathrm{~b}$. From the enhanced view, correlated with the cathode plate geometry (Figure $2 \mathrm{c}-\mathrm{d}$ ), it is clear that the area under the cooling channels contains most of the water. This is an important finding and contrasts with self-breathing fuel cells where substantial build-up of water in open channels has been identified using neutron imaging and standard visualisation techniques [24,49]. Here, the very high flow rate of air through the active channels $\left(5.6 \times 10^{-3} \mathrm{~m}^{3} \mathrm{~s}^{-1}\right)$ dehydrates the fuel cell in locations directly under the open channels by constantly removing most of the water vapour and liquid water 
droplets, substantially hindering its accumulation. On the other hand, in the cooling channels, the cold air cools down the metal plate without removing any of the water, since the electrode is not in direct contact with the air stream.

This result agrees with the model of Xing et al. [36], which describes 10 times more water under the rib than under the channel areas. This feature is also in agreement with the measurements performed under the ribs and channels in closed-cathode configuration, with a dry cathode. The water almost exclusively concentrated under the land, and not under the channels $[82,87]$.

Since the cell is imaged in through-plane mode, it is not possible to assess the location of the water through the thickness of the cell, and differentiate between water in the channel, GDL or membrane. Rather, the through-plane technique provides a quantitative measure of total water content through the plane of the fuel cell at that point.

\subsection{Hydro-Electro-thermal performance analysis}

To understand how the fuel cell's performance is affected by the distribution of water, it is necessary to characterise how the water content is affected by the air flow rate and current density. This is first investigated on a whole-cell scale, looking at the effect of the current and air flow rate on the voltage, temperature and average water content in a cooling channel in the centre of the cell. For further analysis, the localised distributions are investigated via current, temperature and water mapping as a single dataset in the hydro-electro-thermal analysis. 


\subsubsection{Hydro-electro-thermal profile as a function of the air flow rate and current density.}

Electro-thermal performance maps have been introduced in previous work as a novel way to display the influence of the air flow rate and current density on the voltage and temperature of fuel cell operation [88]. Including the water content provides another dimension in understanding the coupled nature of processes occurring in operational fuel cells.

To acquire the 'map' data, a series of four air flow rates, 2.7, 3.9, 4.7 and $5.6 \times 10^{-3}$ $\mathrm{m}^{3} \mathrm{~s}^{-1}$ were investigated, holding the voltage constant for 10 minutes to obtain steady state performance, from open circuit, with an increment of $0.083 \mathrm{~A} \mathrm{~cm}^{-2}$, and the polarisation was interrupted once the voltage dropped below $0.5 \mathrm{~V}$. The entire test, adding an extra 15 minutes to leave the cell to dry and reach ambient temperature between changes of flow rate, lasted 8 hours. Overall, 42 different conditions of current densities and air flow rates were measured. The hydro-thermal profile represents the influence of the air flow rate and current density on the mean cell voltage, and water thickness and temperature of the central cooling channel. It was generated by averaging the neutron images for the last 10 frames ( 2 minutes) prior to the change of current density, then extracting with Image ${ }^{\circledR}$ the average water thickness in the central cooling channel (Figure 2).

The 'electro-thermal' map is coupled with the 'hydro-thermal' map, to form a socalled 'hydro-electro-thermal' profile; this allows analysis of the link between current density, temperature, water content and air flow rate (Figure 3).

An initial hydration of the cell occurs between 0 and $0.4 \mathrm{~A} \mathrm{~cm}^{-2}$, in the activation and beginning of the ohmic predominance region. This is the cell self-hydration, as the 
amount of water generated increases with increasing load, as described by Faraday's Law; while the low temperature $\left(<40{ }^{\circ} \mathrm{C}\right)$ is in favour of water condensation [89]. A maximum hydration is reached between 35 and $45^{\circ} \mathrm{C}$, for a current density between 0.35 and $0.67 \mathrm{~A} \mathrm{~cm}^{-2}$ for low and high air flow rate, respectively. This corresponds to the centre of the ohmic region on the electrothermal map. It overlaps with the optimum operating zone, determined using the current of lowest resistance, introduced in previous work [88]. Gradual dehydration starts above $45^{\circ} \mathrm{C}$, with a 'dry' state reached above $60^{\circ} \mathrm{C}$.

These results confirm the conclusions from previous work based on electro-thermal profiles alone [88], which showed that the purely ohmic resistance (proxy for membrane hydration) initially drops (during self-hydration), reaches a plateau, and then increases above $60^{\circ} \mathrm{C}$ during the dehydration. This hydration / dehydration process has been experimentally reported for self-breathing, open-cathode fuel cells [46], and modelled [89]; but only now can the role of water be confirmed.

To fully understand the hydro-electro-thermal process and its direct influence on the voltage decay across a polarisation, it is necessary to investigate the localised maps and full scale neutron images.

\subsubsection{Locally resolved hydro-electro-thermal maps.}

In order to understand how the current density, temperature and the water content locally affect performance, spatial maps for each quantity were investigated in unison for a given current density and air flow rate. The water maps were generated using the averaging over 2 minutes prior to the change of current density. 
At open circuit potential, the cell is entirely dry, as discussed earlier (Figure 2a) and has an even temperature of $25 \pm 0.2^{\circ} \mathrm{C}$ across the cell (ambient).

The operating points labelled (a) to (f) in Figure 3 were selected to represent the range of operation from 'low' (a-b, between $25-40^{\circ} \mathrm{C}$ ), 'intermediate' (c-d, between 40-50 ${ }^{\circ} \mathrm{C}$ ) and 'high' current densities (e-f between $50-75^{\circ} \mathrm{C}$ ). Initially, at (a), (Figure 4), water is only observed towards the air exhaust, and in the cooling channels (10$15 \mu \mathrm{m})$. This water gradient is caused by the higher current density (0.097-0.085 A $\left.\mathrm{cm}^{-2}\right)$, whereas it is lower near the air inlet $\left(0.078-0.071 \mathrm{~A} \mathrm{~cm}^{-2}\right)$. The temperature variation across the cell is only $1^{\circ} \mathrm{C}$. For all of the points measured (a-f) there is a general decrease in current density from the hydrogen inlet to outlet (left to right in the figures), this is associated with consumption of the hydrogen as it flow through the cell.

At (b), the hydro map reveals that the cell has fully self-hydrated, with water present in the entire cooling channel $(40-100 \mu \mathrm{m})$, and to some extent in the active channels $(5 \mu \mathrm{m})$. Higher water content is observed near the air exhaust with 75-90 $\mu \mathrm{m}$, against 40-45 $\mu \mathrm{m}$ near the air inlet, consistent with the current density gradient. The higher temperature near the air exhaust increases the reaction rate, hence causing a higher current density.

Relatively uniform water profiles exist under the cooling channels across the extent of the cell at (c) and (d) (Figure 5). Although the current density is higher near the air exhaust, and will result in more water generation, more water evaporates due to the higher temperature $\left(\sim 40^{\circ} \mathrm{C}\right)$; hence water distribution is balanced along the air channel direction.

Closer analysis of the water content along the central channel for point (c) and (d) is shown in Figure 6. The quantitative profiles show that despite generating more 
current in (d), the higher temperature leads to greater evaporation and a decrease in the water thickness. Effectively, the entire cell is starting to dehydrate, with an increase in the evaporation rate.

Figure 7 shows two points (e-f), into the dehydration zone, with distinctively different features from the ones observed in a-d. As the total current increases, the regime of operation changes such that a combination of factors result in a local minimum in the current distribution along the air channel flow direction, as seen in (e). The substantial increase in temperature towards the air exhaust acts to evaporate water from the MEA, compromising membrane hydration and limiting the ability to generate more current. However, the cooling effect of the air intake means that the entrance region retains hydration, allowing the current to continue to increase.

As the load is increased further into region (f), the cell temperature towards the air exit reaches $74^{\circ} \mathrm{C}$ and the cell is substantially dehydrated. The water profile is now inverted from that at point (a), a slight amount of water only discernible near the air inlet $(5-15 \mu \mathrm{m})$. This means that the current is now greatest at the air inlet and goes through a minimum further along the air channel.

Overall, this cell dehydration is caused by the limitations in the cooling. The hydroelectro-thermal mapping reveals that evenly distributed amounts of water across the cell ensure stable and optimum performance. Operations around 45 to $50{ }^{\circ} \mathrm{C}$ at high load hinders water evaporation. Therefore, this is a target for the operations of aircooled open cathode fuel cells. Up to a point, increasing the air flow rate would regulate the temperature and enable higher loads; however, the subsequent parasitic power losses would significantly increase, as highlighted in previous studies [90], and a suitable trade-off needs to be determined. 


\section{Conclusion}

A new approach for probing the operation of open-cathode, air-breathing fuel cells has been presented that uses a 'hydro-electro-thermal' mapping process through the combined use of water imaging, current and temperature mapping. This methodology allows the action of hydration and dehydration to be studied under different load and flow rate conditions and allows zones of optimal operation to be identified. Water accumulates mainly under the cooling channels, which is analogous to the land in conventional closed-cathode systems.

Water removal within the cell is determined by local temperature, flow of air in the active channels and the transport of water from under the cooling channels into the active channels. Other factors are likely to affect the transport of water, such as the gas diffusion layer thickness, porosity, hydrophobicity and degree of compression, as well as the electrolyte membrane properties.

Finally, it should be noted that all three techniques are required to be used in unison in order to obtain a complete picture of water management. This approach allows the complex mechanisms that determine the generation, accumulation, transport and removal of water in operating fuel cells to be investigated.

\section{Acknowledgements}

The authors would like to acknowledge the EPSRC for supporting the Electrochemical Innovation Lab through (EP/M009394/1, EP/G030995/1, $\mathrm{EP} / 1037024 / 1, \mathrm{EP} / \mathrm{M} 014371 / 1$ and EP/M023508/1). The authors acknowledge the 
support of Intelligent Energy and UCL for supporting the studentship of Meyer, EPSRC ELEVATE project for currently supporting Meyer and the RAEng for supporting Shearing. The neutron imaging work was carried out with the support of the European Community. The authors appreciate the support of the European Research Infrastructure H2FC (funded under the FP7 specific programme Capacities, Grant Agreement Number 284522) and its partner PSI. Financial support by the Austrian Ministry of Transport, Innovation and Technology (BMVIT) and The Austrian Research Promotion Agency (FFG) is gratefully acknowledged for the funding of the A3FALCON Project. We also thank Dr Denis Kramer for many useful discussions.

\section{References}

[1] D. Gerteisen, W. Mérida, T. Kurz, P. Lupotto, M. Schwager, C. Hebling, Spatially Resolved Voltage, Current and Electrochemical Impedance Spectroscopy Measurements, Fuel Cells. 11 (2011) 339-349.

[2] D.J.L. Brett, S. Atkins, N.P. Brandon, V. Vesovic, N. Vasileiadis, A.R. Kucernak, Measurement of the current distribution along a single flow channel of a solid polymer fuel cell, Electrochem. Commun. 3 (2001) 628-632.

[3] I. Alaefour, G. Karimi, K. Jiao, S. Al Shakhshir, X. Li, Experimental study on the effect of reactant flow arrangements on the current distribution in proton exchange membrane fuel cells, Electrochim. Acta. 56 (2011) 2591-2598.

[4] J. Kleemann, F. Finsterwalder, W. Tillmetz, Characterisation of mechanical behaviour and coupled electrical properties of polymer electrolyte membrane fuel cell gas diffusion layers, J. Power Sources. 190 (2009) 92-102.

[5] D.J.L. Brett, S. Atkins, N.P. Brandon, N. Vasileiadis, V. Vesovic, A.R. Kucernak, Membrane resistance and current distribution measurements under various operating conditions in a polymer electrolyte fuel cell, J. Power Sources. 172 (2007) 2-13.

[6] M. Santis, S.A. Freunberger, M. Papra, A. Wokaun, N.B. Felix, Experimental investigation of coupling phenomena in polymer electrolyte fuel cell stacks, J. Power Sources. 161 (2006) 1076-1083.

[7] D. Gerteisen, N. Zamel, C. Sadeler, F. Geiger, V. Ludwig, C. Hebling, Effect of operating conditions on current density distribution and high frequency resistance in a segmented PEM fuel cell, Int. J. Hydrogen Energy. 37 (2012) $7736-7744$. 
[8] M.M. Mench, C.Y. Wang, M. Ishikawa, In Situ Current Distribution Measurements in Polymer Electrolyte Fuel Cells, J. Electrochem. Soc. 150 (2003) A1052-A1059.

[9] J.J. Hwnag, W.R. Chang, R.G. Peng, P.Y. Chen, A. Su, Experimental and numerical studies of local current mapping on a PEM fuel cell, Int. J. Hydrogen Energy. 33 (2008) 5718-5727.

[10] Y. Yu, X.-Z. Yuan, H. Li, E. Gu, H. Wang, G. Wang, et al., Current mapping of a proton exchange membrane fuel cell with a segmented current collector during the gas starvation and shutdown processes, Int. J. Hydrogen Energy. 37 (2012) 15288-15300.

[11] I. Alaefour, G. Karimi, K. Jiao, X. Li, Measurement of current distribution in a proton exchange membrane fuel cell with various flow arrangements - A parametric study, Appl. Energy. 93 (2012) 80-89.

[12] F.N. Büchi, A.B. Geiger, R.P. Neto, Dependence of current distribution on water management in PEFC of technical size, J. Power Sources. 145 (2005) 62-67.

[13] M. Wilkinson, M. Blanco, E. Gu, J.J. Martin, D.P. Wilkinson, J.J. Zhang, et al., In Situ Experimental Technique for Measurement of Temperature and Current Distribution in Proton Exchange Membrane Fuel Cells, Fuel Cell. 9 (2006) 507-511.

[14] M. Matian, A. Marquis, D. Brett, N. Brandon, An experimentally validated heat transfer model for thermal management design in polymer electrolyte membrane fuel cells, Proc. Inst. Mech. Eng. Part A J. Power Energy. 224 (2010) 1069-1081.

[15] G. Zhang, L. Guo, L. Ma, H. Liu, Simultaneous measurement of current and temperature distributions in a proton exchange membrane fuel cell, J. Power Sources. 195 (2010) 3597-3604.

[16] O. Lottin, T. Colinart, S. Chupin, S. Didierjean, A multi-instrumented polymer exchange membrane fuel cell $\square$ : Observation of the in-plane nonhomogeneities, J. Power Sources. 180 (2008) 748-754.

[17] M. Wang, H. Guo, C. Ma, Temperature distribution on the MEA surface of a PEMFC with serpentine channel flow bed, J. Power Sources. 157 (2006) 181187.

[18] A. Hakenjos, H. Muenter, U. Wittstadt, C. Hebling, A PEM fuel cell for combined measurement of current and temperature distribution, and flow field flooding, J. Power Sources. 131 (2004) 213-216.

[19] L.S. Martins, J.E.F.C. Gardolinski, J.V.C. Vargas, J.C. Ordonez, S.C. Amico, M.M.C. Forte, The experimental validation of a simplified PEMFC simulation model for design and optimization purposes, Appl. Therm. Eng. 29 (2009) 3036-3048.

[20] R. Shimoi, M. Masuda, K. Fushinobu, Y. Kozawa, K. Okazaki, Visualization of the Membrane Temperature Field of a Polymer Electrolyte Fuel Cell, J. Energy Resour. Technol. 126 (2004) 258-261.

[21] M. Matian, A.J. Marquis, N.P. Brandon, Application of thermal imaging to validate a heat transfer model for polymer electrolyte fuel cells, Int. J. Hydrogen Energy. 35 (2010) 12308-12316.

[22] D.J.L. Brett, P. Aguiar, R. Clague, a. J. Marquis, S. Schöttl, R. Simpson, et al., Application of infrared thermal imaging to the study of pellet solid oxide fuel cells, J. Power Sources. 166 (2007) 112-119. 
[23] O.A. Obeisun, Q. Meyer, J. Robinson, C.W. Gibbs, A.R. Kucernak, P. Shearing, et al., Advanced diagnostics applied to a self-breathing fuel cell O. A. Obeisun, ECS Trans. 61 (2014) 249-258.

[24] O. Obeisun, Q. Meyer, J. Robinson, C.W. Gibbs, A.R. Kucernak, P.R. Shearing, et al., Development of open-cathode polymer electrolyte fuel cells using printed circuit board flow-field plates: Flow geometry characterisation, Int. J. Hydrogen Energy. 39 (2014) 18326-18336.

[25] O.A. Obeisun, Q. Meyer, E. Engebretsen, D.P. Finegan, J.B. Robinson, P.R. Shearing, et al., Effect of current density and flow plate orientation on water management in an opencathode fuel cell using thermal imaging, gravimetric analysis and water droplet visualisation, Int. J. Hydrog. Energy, Submitt. (n.d.).

[26] Q. Meyer, S. Ashton, O. Curnick, T. Reisch, P. Adcock, K. Ronaszegi, et al., Dead-Ended Anode Polymer Electrolyte Fuel Cell Stack Operation Investigated using Electrochemical Impedance Spectroscopy, Off-gas Analysis and Thermal Imaging, J. Power Sources. 254 (2013) 1-9.

[27] M. Noorkami, J.B. Robinson, Q. Meyer, O.A. Obeisun, E.S. Fraga, T. Reisch, et al., Effect of temperature uncertainty on polymer electrolyte fuel cell performance5, Int. J. Hydrogen Energy. 39 (2014) 1439-1448.

[28] K. Jiao, I.E. Alaefour, G. Karimi, X. Li, Simultaneous measurement of current and temperature distributions in a proton exchange membrane fuel cell during cold start processes, Electrochim. Acta. 56 (2011) 2967-2982.

[29] A. Hakenjos, C. Hebling, Spatially resolved measurement of PEM fuel cells, J. Power Sources. 145 (2005) 307-311.

[30] T.E. Springer, T.A. Zawodzinski, S. Gottesfeld, Polymer Electrolyte Fuel Cell Model, J. Electrochem. Soc. 138 (1993) 2334-2342.

[31] B. Siversten, N. Djilali, CFD-based modelling of proton exchange membrane fuel cells, J. Power Sources. 141 (2005) 65-78.

[32] A. Iranzo, P. Boillat, F. Rosa, Validation of a three dimensional PEM fuel cell CFD model using local liquid water distributions measured with neutron imaging, Int. J. Hydrogen Energy. 39 (2014) 7089-7099.

[33] N. Djilali, Computational modelling of polymer electrolyte membrane (PEM) fuel cells: Challenges and opportunities, Energy. 32 (2007) 269-280.

[34] Y. Zong, B. Zhou, A. Sobiesiak, Water and thermal management in a single PEM fuel cell with non-uniform stack temperature, J. Power Sources. 161 (2006) 143-159.

[35] S. Chaudhary, V.K. Sachan, P.K. Bhattacharya, Two dimensional modelling of water uptake in proton exchange membrane fuel cell, Int. J. Hydrogen Energy. 39 (2014) 17802-17818.

[36] L. Xing, X. Liu, T. Alaje, R. Kumar, M. Mamlouk, K. Scott, A two-phase flow and non-isothermal agglomerate model for a proton exchange membrane (PEM) fuel cell, Energy. 73 (2014) 618-634.

[37] J. Stumper, M. Löhr, S. Hamada, Diagnostic tools for liquid water in PEM fuel cells, J. Power Sources. 143 (2005) 150-157.

[38] T. Matsuura, J. Chen, J.B. Siegel, A.G. Stefanopoulou, Degradation phenomena in PEM fuel cell with dead-ended anode, Int. J. Hydrogen Energy. 38 (2013) 11346-11356.

[39] J. Pino, F. Rosa, A. Iranzo, M. Mun, E. Lo, Experimental fuel cell performance analysis under different operating conditions and bipolar plate designs, Int. J. Hydrogen Energy. 5 (2010) 11437-11447. 
[40] T. Kurz, A. Hakenjos, J. Krämer, M. Zedda, C. Agert, An impedance-based predictive control strategy for the state-of-health of PEM fuel cell stacks, J. Power Sources. 180 (2008) 742-747.

[41] Q. Yan, H. Toghiani, J. Wu, Investigation of water transport through membrane in a PEM fuel cell by water balance experiments, J. Power Sources. 158 (2006) 316-325.

[42] X. Yuan, J.C. Sun, H. Wang, J. Zhang, AC impedance diagnosis of a 500W PEM fuel cell stack, J. Power Sources. 161 (2006) 929-937.

[43] T.J. Mason, J. Millichamp, T.P. Neville, P.R. Shearing, S. Simons, D.J.L. Brett, A study of the effect of water management and electrode flooding on the dimensional change of polymer electrolyte fuel cells, J. Power Sources. 242 (2013) 70-77.

[44] A. Hakenjos, M. Zobel, J. Clausnitzer, C. Hebling, Simultaneous electrochemical impedance spectroscopy of single cells in a PEM fuel cell stack, J. Power Sources. 154 (2006) 360-363.

[45] I.A. Schneider, D. Kramer, A. Wokaun, G.G. Scherer, Spatially resolved characterization of PEFCs using simultaneously neutron radiography and locally resolved impedance spectroscopy, Electrochem. Commun. 7 (2005) 1393-1397.

[46] T. Fabian, J.D. Posner, R. O'Hayre, S.-W. Cha, J.K. Eaton, F.B. Prinz, et al., The role of ambient conditions on the performance of a planar, air-breathing hydrogen PEM fuel cell, J. Power Sources. 161 (2006) 168-182.

[47] D. Spernjak, S.G. Advani, A.K. Prasad, Simultaneous Neutron and Optical Imaging in PEM Fuel Cells, J. Electrochem. Soc. 156 (2009) B109.

[48] Y.-S. Chen, H. Peng, D.S. Hussey, D.L. Jacobson, D.T. Tran, T. Abdel-Baset, et al., Water distribution measurement for a PEMFC through neutron radiography, J. Power Sources. 170 (2007) 376-386.

[49] M. Weiland, P. Boillat, P. Oberholzer, a. Kaestner, E.H. Lehmann, T.J. Schmidt, et al., High resolution neutron imaging for pulsed and constant load operation of passive self-breathing polymer electrolyte fuel cells, Electrochim. Acta. 87 (2013) 567-574.

[50] P. Boillat, D. Kramer, B.C. Seyfang, G. Frei, E. Lehmann, G.G. Scherer, et al., In situ observation of the water distribution across a PEFC using high resolution neutron radiography, Electrochem. Commun. 10 (2008) 546-550.

[51] A. Iranzo, P. Boillat, P. Oberholzer, J. Guerra, A novel approach coupling neutron imaging and numerical modelling for the analysis of the impact of water on fuel cell performance, Energy. 68 (2014) 971-981.

[52] J. Zhang, D. Kramer, R. Shimoi, Y. Ono, E. Lehmann, A. Wokaun, et al., In situ diagnostic of two-phase flow phenomena in polymer electrolyte fuel cells by neutron imaging, Electrochim. Acta. 51 (2006) 2715-2727.

[53] P. Oberholzer, P. Boillat, R. Siegrist, R. Perego, a. Kästner, E. Lehmann, et al., Cold-Start of a PEFC Visualized with High Resolution Dynamic In-Plane Neutron Imaging, J. Electrochem. Soc. 159 (2012) B235.

[54] E.H. Lehmann, P. Boillat, G. Scherrer, G. Frei, Fuel cell studies with neutrons at the PSI's neutron imaging facilities, Nucl. Instruments Methods Phys. Res. Sect. A Accel. Spectrometers, Detect. Assoc. Equip. 605 (2009) 123-126.

[55] J.B. Siegel, D.A. McKay, A.G. Stefanopoulou, D.S. Hussey, D.L. Jacobson, Measurement of Liquid Water Accumulation in a PEMFC with Dead-Ended Anode, J. Electrochem. Soc. 155 (2008) B1168-B1178. 
[56] D. Kramer, J. Zhang, R. Shimoi, E. Lehmann, A. Wokaun, K. Shinohara, et al., In situ diagnostic of two-phase flow phenomena in polymer electrolyte fuel cells by neutron imaging, Electrochim. Acta. 50 (2005) 2603-2614.

[57] R. Satija, D.L. Jacobson, M. Arif, S. a. Werner, In situ neutron imaging technique for evaluation of water management systems in operating PEM fuel cells, J. Power Sources. 129 (2004) 238-245.

[58] H. Murakawa, K. Sugimoto, K. Miyata, H. Asano, N. Takenaka, Y. Saito, Visualization of Water Behavior in the In-plane and Throughplane Directions in a PEFC using a Neutron Image Intensifier, Phys. Procedia. 43 (2013) 277281.

[59] A.B. Geiger, A. Tsukada, E. Lehmann, P. Vontobel, A. Wokaun, G.G. Scherer, In Situ Investigation of Two-Phase Flow Patterns in Flow Fields of PEFC's Using Neutron Radiography, (2002) 92-98.

[60] J.M. LaManna, S. Chakraborty, J.J. Gagliardo, M.M. Mench, Isolation of transport mechanisms in PEFCs using high resolution neutron imaging, Int. J. Hydrogen Energy. 39 (2014) 3387-3396.

[61] H. Iwase, S. Koizumi, H. likura, M. Matsubayashi, D. Yamaguchi, Y. Maekawa, et al., A combined method of small-angle neutron scattering and neutron radiography to visualize water in an operating fuel cell over a wide length scale from nano to millimeter, Nucl. Instruments Methods Phys. Res. Sect. A Accel. Spectrometers, Detect. Assoc. Equip. 605 (2009) 95-98.

[62] N. Pekula, K. Heller, P. a. Chuang, a. Turhan, M.M. Mench, J.S. Brenizer, et al., Study of water distribution and transport in a polymer electrolyte fuel cell using neutron imaging, Nucl. Instruments Methods Phys. Res. Sect. A Accel. Spectrometers, Detect. Assoc. Equip. 542 (2005) 134-141.

[63] T.A. Trabold, J.P. Owejan, D.L. Jacobson, M. Arif, P.R. Huffman, In situ investigation of water transport in an operating PEM fuel cell using neutron radiography: Part 1 - Experimental method and serpentine flow field results, Int. J. Heat Mass Transf. 49 (2006) 4712-4720.

[64] M.A. Hickner, N.P. Siegel, K.S. Chen, D.S. Hussey, D.L. Jacobson, M. Arif, In Situ High-Resolution Neutron Radiography of Cross-Sectional Liquid Water Profiles in Proton Exchange Membrane Fuel Cells, J. Electrochem. Soc. 155 (2008) B427.

[65] M.A. Hickner, K.S. Chen, N.P. Siegel, Elucidating Liquid Water Distribution and Removal in an Operating Proton Exchange Membrane Fuel Cell via Neutron Radiography, J. Fuel Cell Sci. Technol. 7 (2010) 011001.

[66] C. Hartnig, I. Manke, N. Kardjilov, a. Hilger, M. Grünerbel, J. Kaczerowski, et al., Combined neutron radiography and locally resolved current density measurements of operating PEM fuel cells, J. Power Sources. 176 (2008) 452-459.

[67] A. Schmitz, M. Tranitz, S. Wagner, R. Hahn, C. Hebling, Planar self-breathing fuel cells, J. Power Sources. 118 (2003) 162-171.

[68] R. Hahn, S. Wagner, A. Schmitz, H. Reichl, Development of a planar micro fuel cell with thin film and micro patterning technologies, J. Power Sources. 131 (2004) 73-78.

[69] S.U. Jeong, E.A. Cho, H.-J. Kim, T.-H. Lim, I.-H. Oh, S.H. Kim, A study on cathode structure and water transport in air-breathing PEM fuel cells, J. Power Sources. 159 (2006) 1089-1094. 
[70] S.U. Jeong, E.A. Cho, H.-J. Kim, T.-H. Lim, I.-H. Oh, S.H. Kim, Effects of cathode open area and relative humidity on the performance of air-breathing polymer electrolyte membrane fuel cells, J. Power Sources. 158 (2006) 348353.

[71] N. Bussayajarn, H. Ming, K.K. Hoong, W.Y. Ming Stephen, C.S. Hwa, Planar air breathing PEMFC with self-humidifying MEA and open cathode geometry design for portable applications, Int. J. Hydrogen Energy. 34 (2009) 77617767.

[72] T. Fabian, R. O'Hayre, S. Litster, F.B. Prinz, J.G. Santiago, Passive water management at the cathode of a planar air-breathing proton exchange membrane fuel cell, J. Power Sources. 195 (2010) 3201-3206.

[73] D.T.S. Rosa, D.G. Pinto, V.S. Silva, R.A. Silva, C.M. Rangel, High performance PEMFC stack with open-cathode at ambient pressure and temperature conditions, Int. J. Hydrogen Energy. 32 (2007) 4350-4357.

[74] J. Wu, S. Galli, I. Lagana, A. Pozio, G. Monteleone, X. Zi, et al., An air-cooled proton exchange membrane fuel cell with combined oxidant and coolant flow, J. Power Sources. 188 (2009) 199-204.

[75] G. Jung, K. Lo, A. Su, F. Weng, C. Tu, T. Yang, et al., Experimental evaluation of an ambient forced-feed air-supply PEM fuel cell, Int. J. Hydrogen Energy. 33 (2008) 2980-2985.

[76] A.P. Sasmito, E. Birgersson, K.W. Lum, A.S. Mujumdar, Fan selection and stack design for open-cathode polymer electrolyte fuel cell stacks, Renew. Energy. 37 (2012) 325-332.

[77] B. Kim, Y. Lee, A. Woo, Y. Kim, Effects of cathode channel size and operating conditions on the performance of air-blowing PEMFCs, Appl. Energy. 111 (2013) 441-448.

[78] H. Guo, M. Hai, F. Ye, C. Fang, Experimental study of temperature distribution on anodic surface of MEA inside a PEMFC with parallel channels flow bed, Int. J. Hydrogen Energy. 37 (2012) 13155-13160.

[79] C. Wen, G. Huang, Application of a thermally conductive pyrolytic graphite sheet to thermal management of a PEM fuel cell, J. Power Sources. 178 (2008) 132-140.

[80] Q. Meyer, K. Ronaszegi, J.B. Robinson, M. Noorkami, O. Curnick, S. Ashton, et al., Combined Current and Temperature Mapping in an Air-Cooled, OpenCathode Polymer Electrolyte Fuel Cell Under Steady-State and Dynamic Conditions., J. Power Sources, in Press. (2015).

[81] E.H. Lehmann, P. Vontobel, L. Wiezel, Properties of the radiography facility neutral at SINQ and its potential for use as European reference facility, Nondestruct. Test. Eval. 16 (2001) 191-202.

[82] P. Boillat, P. Oberholzer, a. Kaestner, R. Siegrist, E.H. Lehmann, G.G. Scherer, et al., Impact of Water on PEFC Performance Evaluated by Neutron Imaging Combined with Pulsed Helox Operation, J. Electrochem. Soc. 159 (2012) F210-F218.

[83] P. Boillat, Advanced characterization of polymer electrolyte fuel cells using high resolution neutron imaging, ETH, 2009.

[84] A. Iranzo, P. Boillat, Liquid water distribution patterns featuring back-diffusion transport in a PEM fuel cell with neutron imaging, Int. J. Hydrogen Energy. 39 (2014) 17240-17245. 
[85] D.J. Ludlow, C.M. Calebrese, S.H. Yu, C.S. Dannehy, D.L. Jacobson, D.S. Hussey, et al., PEM fuel cell membrane hydration measurement by neutron imaging, J. Power Sources. 162 (2006) 271-278.

[86] J. Owejan, T. Trabold, D. Jacobson, M. Arif, S. Kandlikar, Effects of flow field and diffusion layer properties on water accumulation in a PEM fuel cell, Int. J. Hydrogen Energy. 32 (2007) 4489-4502.

[87] P. Oberholzer, P. Boillat, Local Characterization of PEFCs by Differential Cells: Systematic Variations of Current and Asymmetric Relative Humidity, J. Electrochem. Soc. 161 (2013) F139-F152.

[88] Q. Meyer, K. Ronaszegi, G. Pei-June, O. Curnick, S. Ashton, T. Reisch, et al., Optimisation of air cooled, open-cathode fuel cells: Current of lowest resistance and electro-thermal performance mapping, J. Power Sources. 291 (2015) 261-269.

[89] R. O’Hayre, T. Fabian, S. Litster, F.B. Prinz, J.G. Santiago, Engineering model of a passive planar air breathing fuel cell cathode, J. Power Sources. 167 (2007) 118-129.

[90] Q. Meyer, A. Himeur, S. Ashton, O. Curnick, R. Clague, T. Reisch, et al., System-Level Electro-thermal Optimisation of Air-Cooled Open-Cathode Polymer Electrolyte Fuel Cells: Air Blower Parasitic Load and Schemes for Dynamic Operation., Int. J. Hydrog. Energy. (in Press).

\section{List of Figures:}

Figure 1. (a) Simplified Schematic and picture (b) of the fuel cell set-up for through-plane measurement in NEUTRA [81], facing the LiF/ZnS scintillator.

Figure 2. (a) Neutron imaging at open circuit potential, (b) neutron image at $0.5 \mathrm{~A} \mathrm{~cm}^{-2}, 5.6 \times$ $10^{-3} \mathrm{~m}^{3} \mathrm{~s}^{-1}$; (c) cross-section of the two-cell stack; (d) corresponding through-plane image. 
Figure 3. Hydro-electro-thermal profile of the cell, displaying the "electro-thermal" and "hydro-thermal" maps. (a-f) correspond to representative zones of operation discussed in the text. The saw-tooth shape at high current density is an artefact of the extrapolation.

Figure 4. Localised hydro-electro-thermal maps at points (a) and (b) from Figure 3. The green arrow represents the air flow from inlet to exhaust, the red arrow the hydrogen flow from inlet to exhaust. (a, air flow rate of $5.6 \times 10^{-3} \mathrm{~m}^{3} \mathrm{~s}^{-1} ; \mathrm{b}, 4.7 \times 10^{-3} \mathrm{~m}^{3} \mathrm{~s}^{-1}$ ).

Figure 5. Localised hydro-electro-thermal maps at points (c) and (d) from Figure 4. The green arrow represents the air flow from inlet to exhaust, the red arrow the hydrogen flow from inlet to exhaust. The dashed boxes in the hydro map are further discussed in Figure 6. (c, air flow rate of $5.6 \times 10^{-3} \mathrm{~m}^{3} \mathrm{~s}^{-1} ; \mathrm{d}, 3.9 \times 10^{-3} \mathrm{~m}^{3} \mathrm{~s}^{-1}$ ).

Figure 6. Close up view of the areas of the hydro maps, in (c) and (d) highlighted in Figure 5, and average corresponding water thickness.

Figure 7. Localised hydro-electro-thermal maps at points (e) and (f) from Figure 3. The green arrow represents the air flow, the red arrow the hydrogen flow directions. The dashed ellipse on the hydro map of $(f)$ is used as a guide for the eye. (e, air flow rate of $4.7 \times 10^{-3} \mathrm{~m}^{3} \mathrm{~s}^{-1}$; $f$, $\left.2.7 \times 10^{-3} \mathrm{~m}^{3} \mathrm{~s}^{-1}\right)$. 
Graphical Abstract (for review)

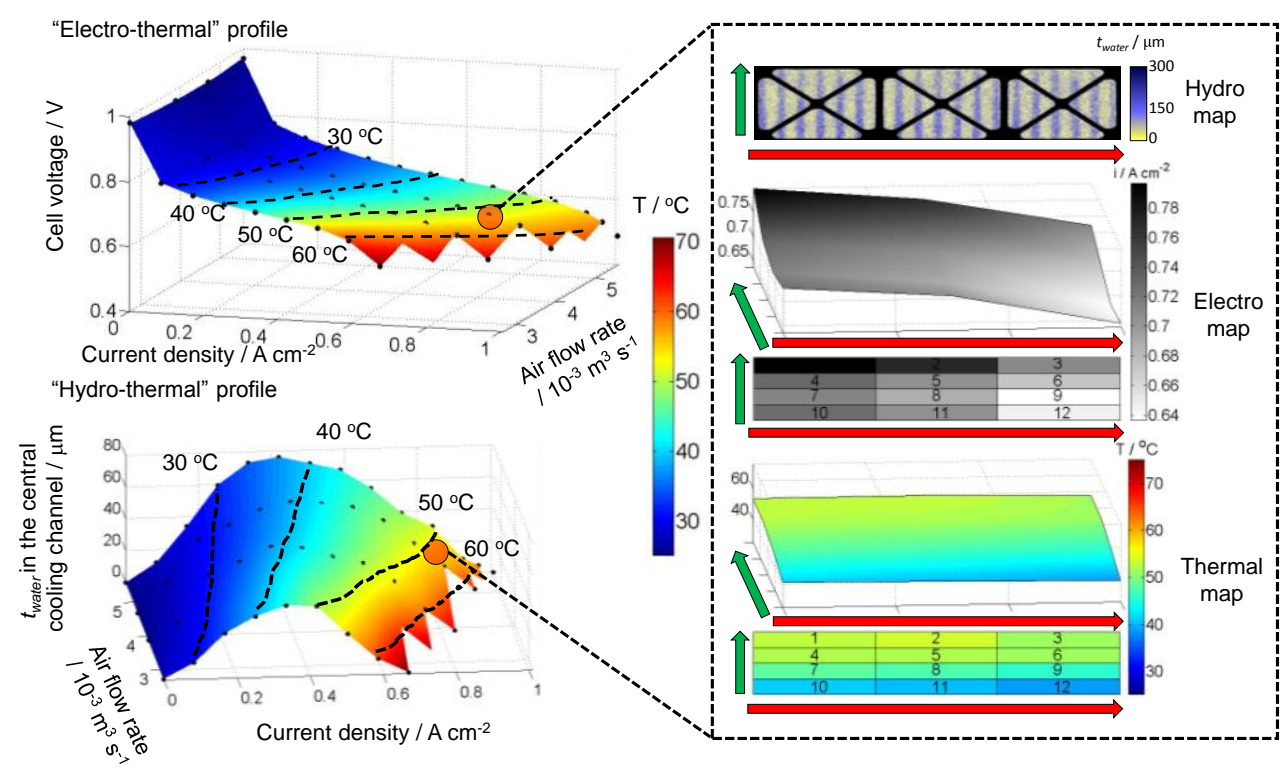




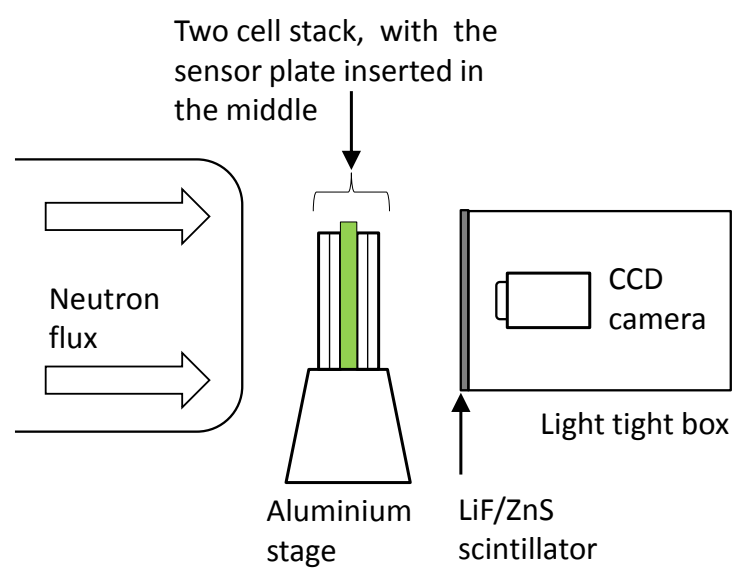

(a)

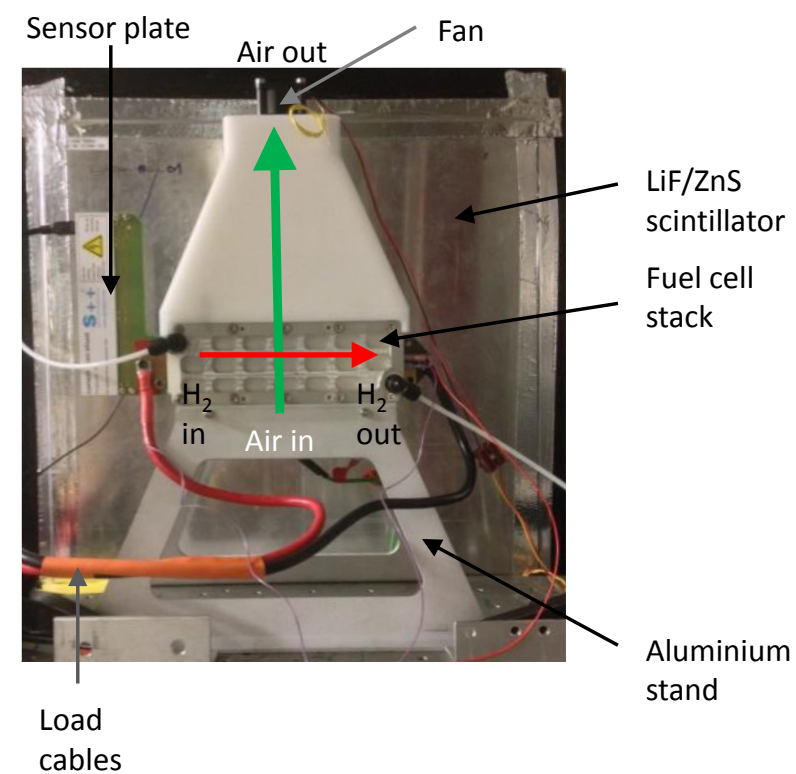

(b) 
Figure 2

(a)

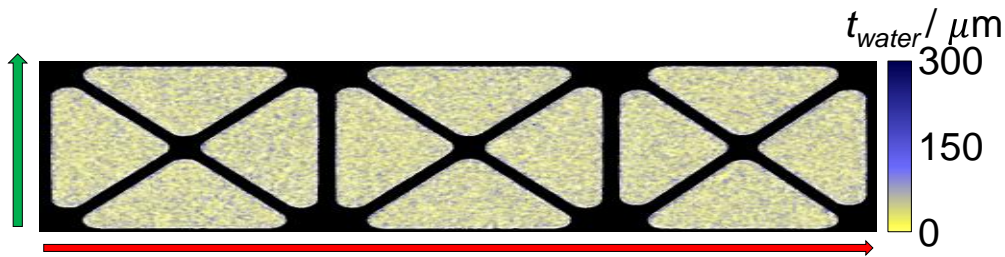

Central cooling channel

(b)

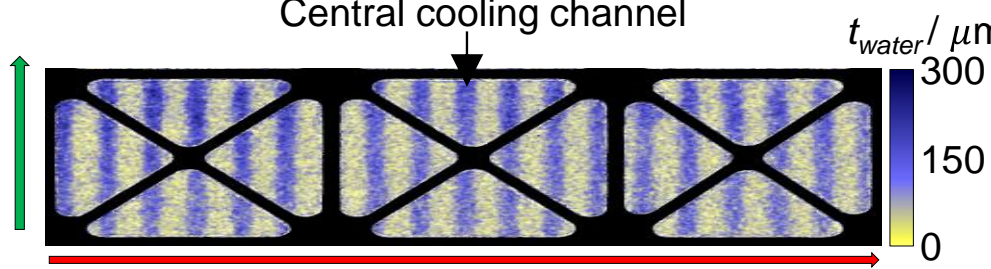

(c)

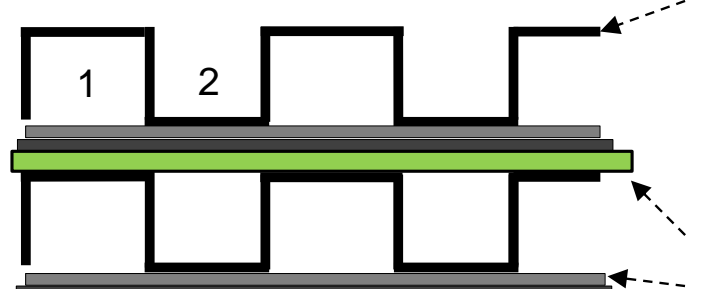

Cathode plate

1. Active channel

2. Cooling channel

Sensor plate

MEA and GDL Anode plate

(d)

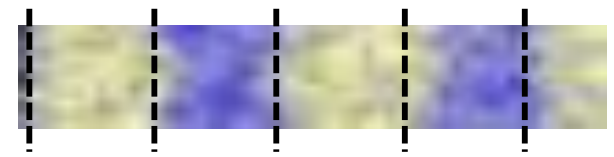


"Electro-thermal" profile

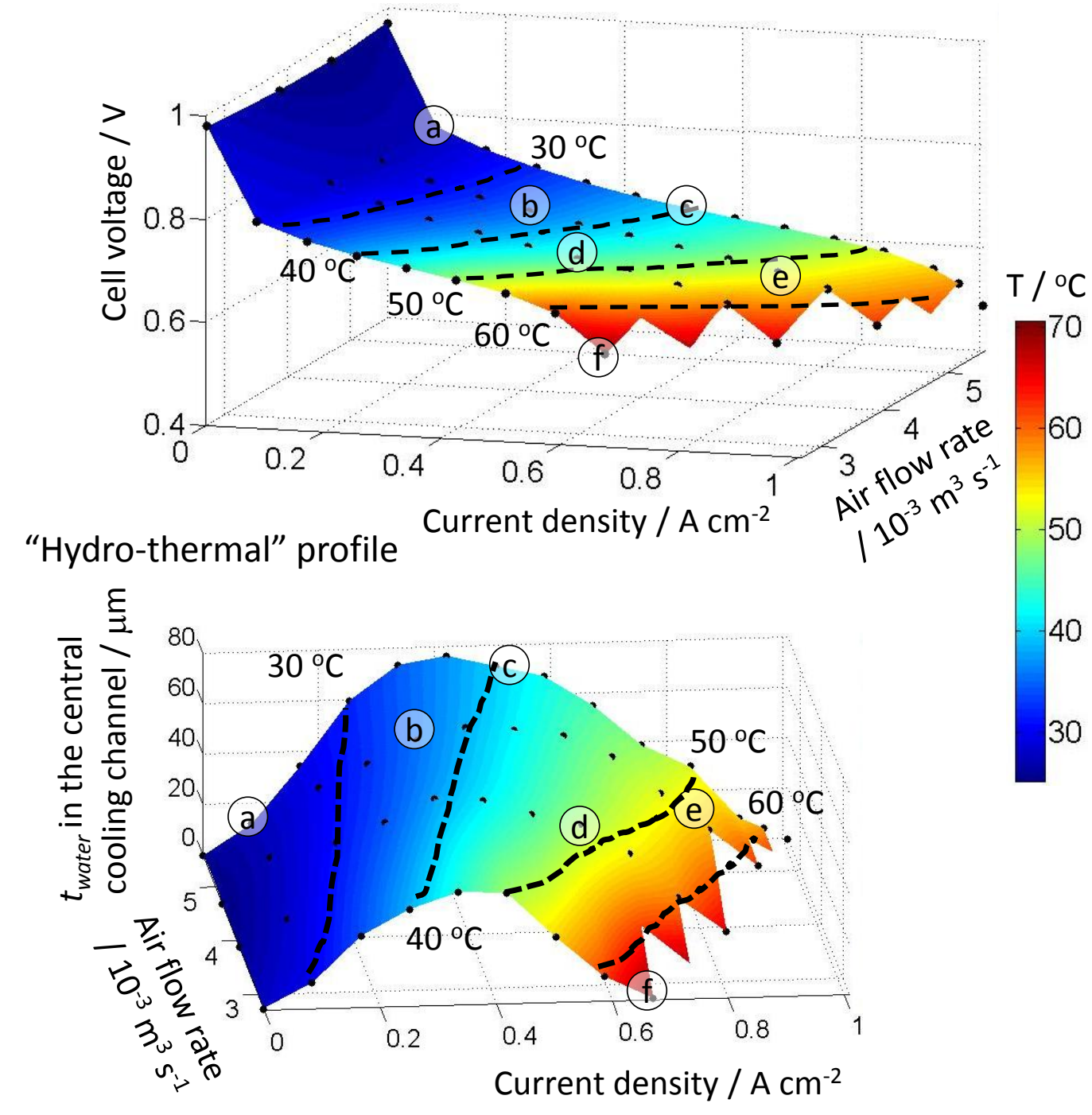




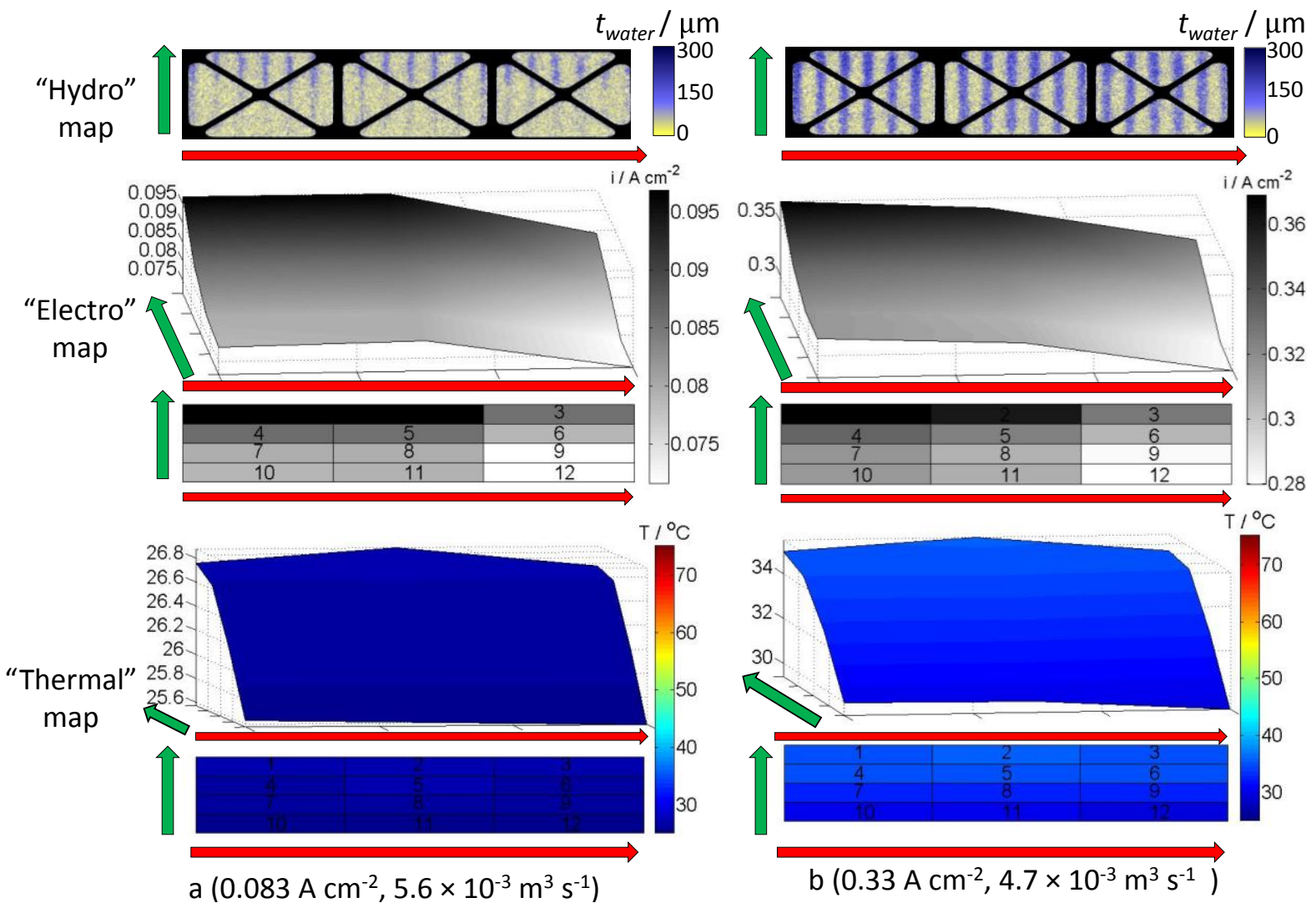




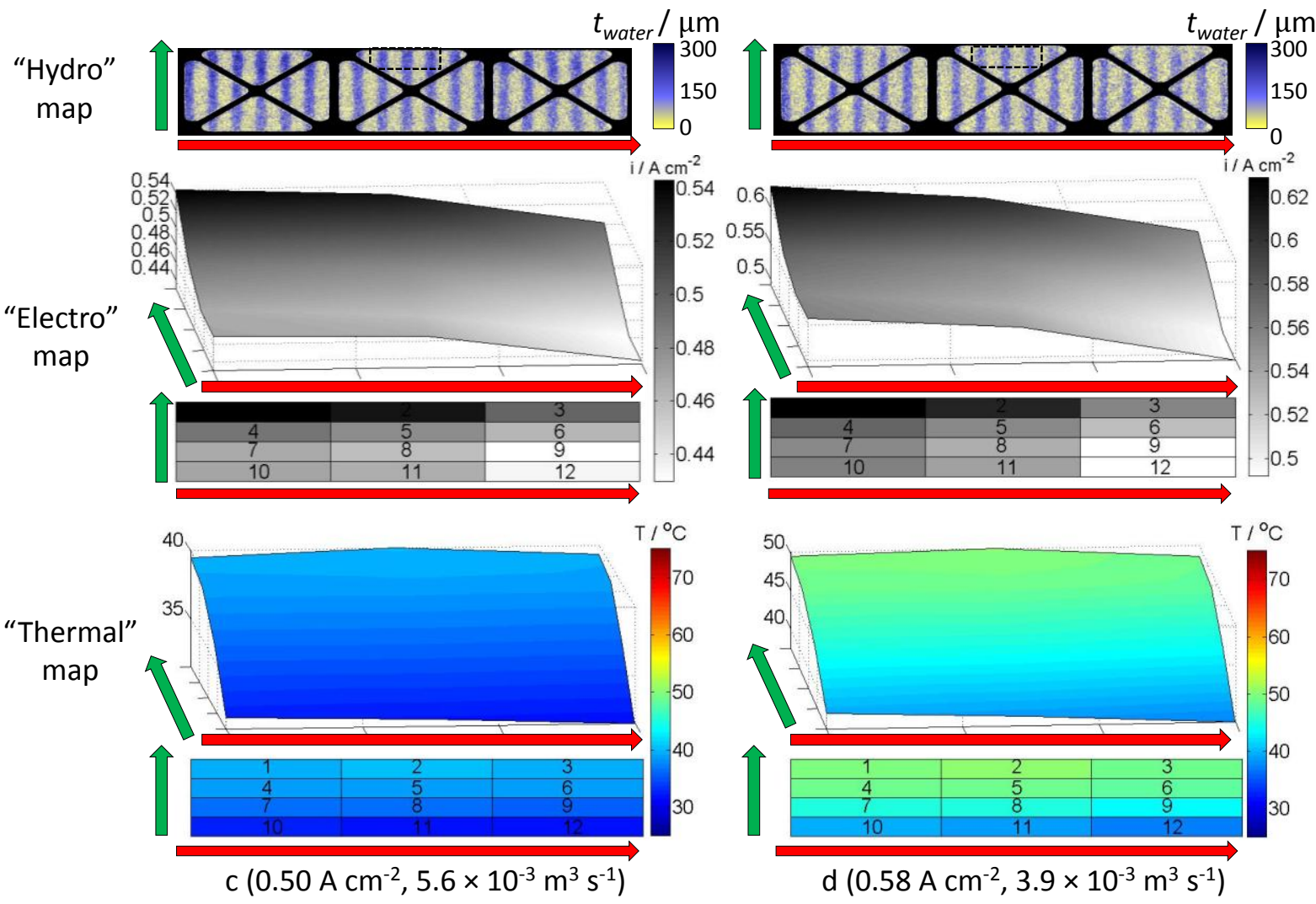


Figure 6

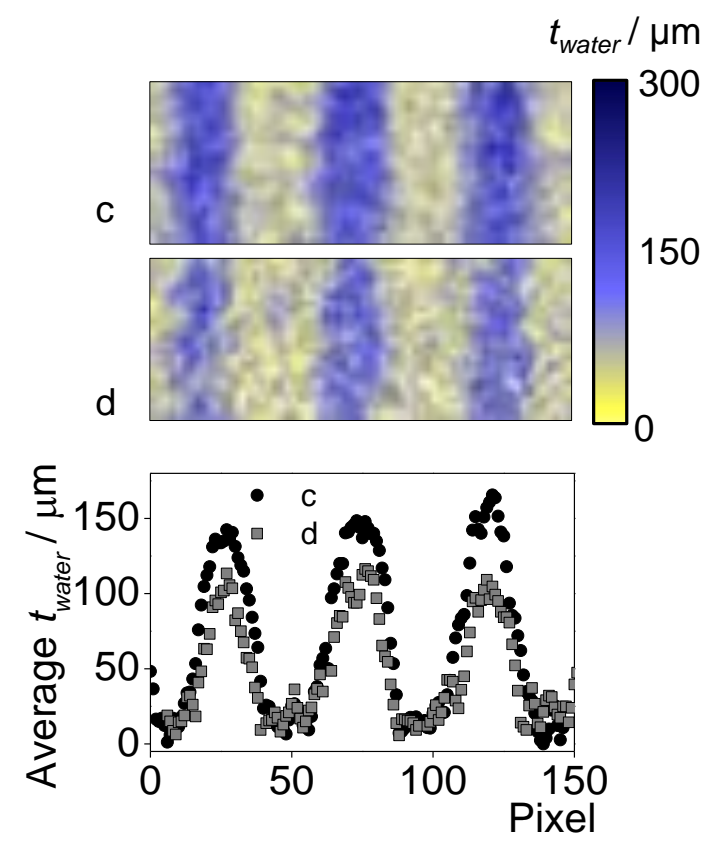


Figure 7

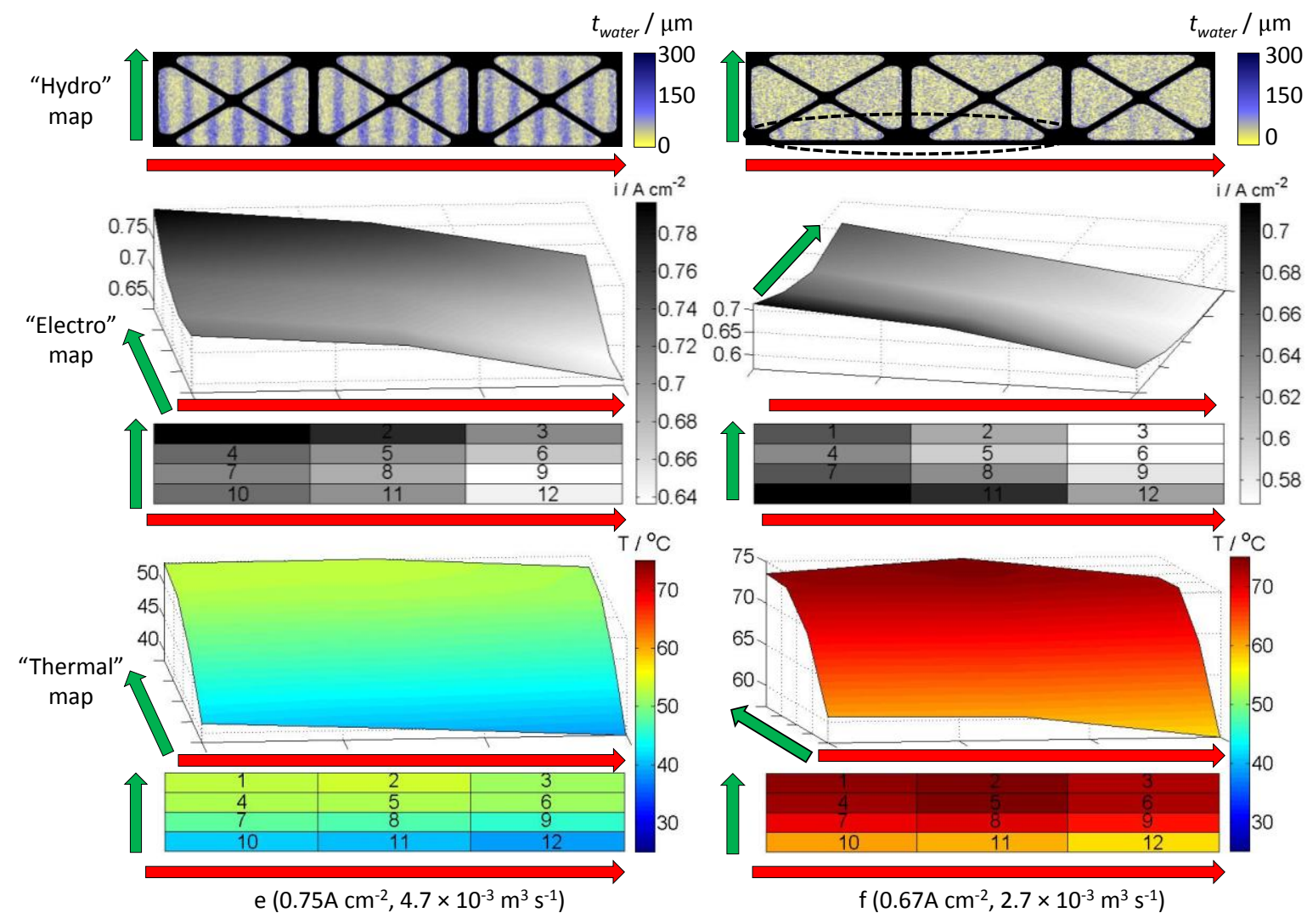

